\title{
Poly(vinyl alcohol)-based Electrospun Nanofibers: Characterization and Phytase Immobilization
}

\author{
Umran Duru Kamaci 1,* iD , Aysegul Peksel 1 (D) \\ 1 Faculty of Arts and Sciences, Department of Chemistry, Yildiz Technical University, 34220 Istanbul, Turkey \\ * Correspondence: umranduru@gmail.com; peksel@yildiz.edu.tr (U.D.K.);
}

Scopus Author ID 57192986172

Received: 19.10.2021; Revised: 15.11.2021; Accepted: 18.11.2021; Published: 25.11.2021

\begin{abstract}
The aim of this study is to immobilization phytase obtained from cowpea seeds into nanofiber-based on poly(vinyl alcohol) (PVA) and to investigate kinetic properties, optimal $\mathrm{pH}$, and temperature of free and immobilized phytase. The structural analysis and morphological properties of the nanofibers are carried out via SEM and XRD. The results indicated that enzyme stability, $\mathrm{pH}$, and thermal stability are increased after immobilizing phytase into the nanofiber. The optimum $\mathrm{pH}$ and temperature of the free and immobilized phytase are found as $\mathrm{pH} 5.0$ and $45-65^{\circ} \mathrm{C}$, respectively. These results indicated that the immobilized phytase could be a good candidate for agriculture, animal feed, food, and medical applications.
\end{abstract}

Keywords: phytase; cowpea seeds; biocatalyst; nanofiber.

(C) 2021 by the authors. This article is an open-access article distributed under the terms and conditions of the Creative Commons Attribution (CC BY) license (https://creativecommons.org/licenses/by/4.0/).

\section{Introduction}

Catalysts are materials that accelerate any reaction without being consumed. Recently, most reactions are effectively performed in the presence of a catalyst, and the efficiency of a complex reaction can be enhanced by using a suitable catalyst. They can be classified in mainly four groups such as biocatalyst, inorganic, organic, and organometallic catalysts [1,2]. Among these catalysts, biocatalysts or enzymes that originated from a natural source can be catalyzed biochemical reactions. They have exhibited superior behaviors in terms of working conditions such as $\mathrm{pH}$ and temperature [3,4]. Also, they have shown good substrate selectivity performance, high efficiency, and productivity with very low energy consumption compared to the other catalysts [5].

Phytase (myo-inositol hexaphosphate phosphohydrolase) is one of the most noticeable enzymes in human health, environmental protection, and nutrition [6,7]. Phytase as a biocatalyst is an enzyme that catalyzes the hydrolysis of myo-inositol phosphates, Myoinositol, and inorganic phosphate by producing ortho-phosphate groups from the inositol core of phytate [8]. According to the literature, phytase has also been widely used in the human diet, food industry, agriculture, and pharmaceutical sectors $[9,10]$. Moreover, this biocatalyst's most preferred industrial application is a feed supplement for some animals such as fish, pigs, and poultry [11]. On the other hand, it is a thermally unstable enzyme that loses its enzymatic activity at high temperatures [12]. The use of phytase in the industry is unfavorably affected due to the thermally unstable property. Therefore, there is still a need to obtain phytase thermally stable. 
Microbial origin enzymes have been generally used in industrial applications of phytase. Therefore, there is a need to develop more economical and effective new sources of phytase. In this study, a new plant origin enzyme source was used for the purification of phytase.

Electrospinning is a versatile technique used to fabricate micro to nanoscale fibers by using inorganic materials, polymers, ceramic, and composites [12-15]. Electrospun fibers have superior properties such as large surface area, biocompatibility, non-toxicity, and porosity [1618]. The fabricated electrospun fibers also have a wide range of applications such as biomedical, biological dressing, drug release, tissue engineering, membrane, catalysis, and enzyme immobilization $[19,20]$. Immobilization of the enzyme on nanomaterials gains strong stability to the enzyme and protects the enzyme against leaching and 3-D structure loss [21]. Also, the enzyme is placed into the porous structure of the fibers, and the $\mathrm{pH}$ or temperature resistance of the enzyme has been improved after the immobilization of the enzyme into the nano/micro-fiber.

In this study, plant-based biocatalyst (cowpea seeds) was used to isolation of phytase, and the isolated enzyme was immobilized into poly(vinyl alcohol) (PVA) nanofibers to obtain recoverable, recyclable, and stable phytase preparations and to improve thermal stability, and catalytic activity of the plant origin phytase. The reason for the new Optimum $\mathrm{pH}$ temperature, kinetic parameters such as $K_{m}$ and $V_{\max }$ of the enzymes were also determined, and the obtained results for the free and immobilized enzyme were compared.

\section{Materials and Methods}

\subsection{Materials.}

Cowpea seeds (Vigna unguiculata) were supplied from the local market. Poly(vinyl alcohol) (PVA, molecular weight $60 \mathrm{kDa}$ ) was purchased from Merck (Germany). The other chemicals were purchased from Sigma Aldrich (Germany), and they were used without any purification.

\subsection{Purification of phytase from cowpea seeds.}

$10 \%(\mathrm{w} / \mathrm{v})$ Cowpea seeds solution was prepared in $0.1 \mathrm{M}$ sodium acetate $(\mathrm{NaOAc})$ buffer, and the $\mathrm{pH}$ value of the buffer solution was adjusted as 5.0. The solution was retained in a refrigerator at $+4{ }^{\circ} \mathrm{C}$ overnight. The next day, they were homogenized with a Waring blender. After homogenization, the homogenate was filtered using a fine muslin, and it was centrifuged at $+4{ }^{\circ} \mathrm{C}$ for $30 \mathrm{~min}$ at $10000 \mathrm{rpm}$. After centrifugation, the pellet was cast out, and the supernatant was acted to $60 \%$ ammonium sulfate $(w: v)$ saturation and the solution was dialyzed by using a dialysis sac, and the dialyzed enzyme was used for phytase activity analysis and was stored at $-20{ }^{\circ} \mathrm{C}$ for further experiment [22].

\subsection{Preparation of phytase-PVA solution.}

Poly(vinyl alcohol) solution $(8 \%, w / v)$ was prepared in $10 \mathrm{~mL} 0.1 \mathrm{M} \mathrm{NaOAc}$ buffer $(\mathrm{pH}$ 5.0). Then, phytase was directly added into PVA solution at different enzyme concentrations $(0.5-2.0 \% ; w / v)$, and it was mixed for $1 \mathrm{~h}$ using magnetic stirring. 


\subsection{Immobilization of phytase via electrospinning.}

Phytase-PVA solution was placed into a $5 \mathrm{~mL}$ syringe $(0.07 \mathrm{~mm}$ diameter needle). The flow rate was adjusted in the range from 0.5 to $2.0 \mathrm{~mL} / \mathrm{h}$, and it was controlled via an infusion pump (New Era Pump System Inc.). The distance between the collector plate and the pump was $13 \mathrm{~cm}$, and the applied voltage was adjusted to $23 \mathrm{kV}$ from DC high voltage power source (PW1010, Elektrosis). Also, PVA fiber was fabricated under the following conditions: voltage $23 \mathrm{kV}$, distance $13 \mathrm{~cm}$, and flow rate $1 \mathrm{~mL} / \mathrm{h}$ as the control group for characterization (Figure $1)$.

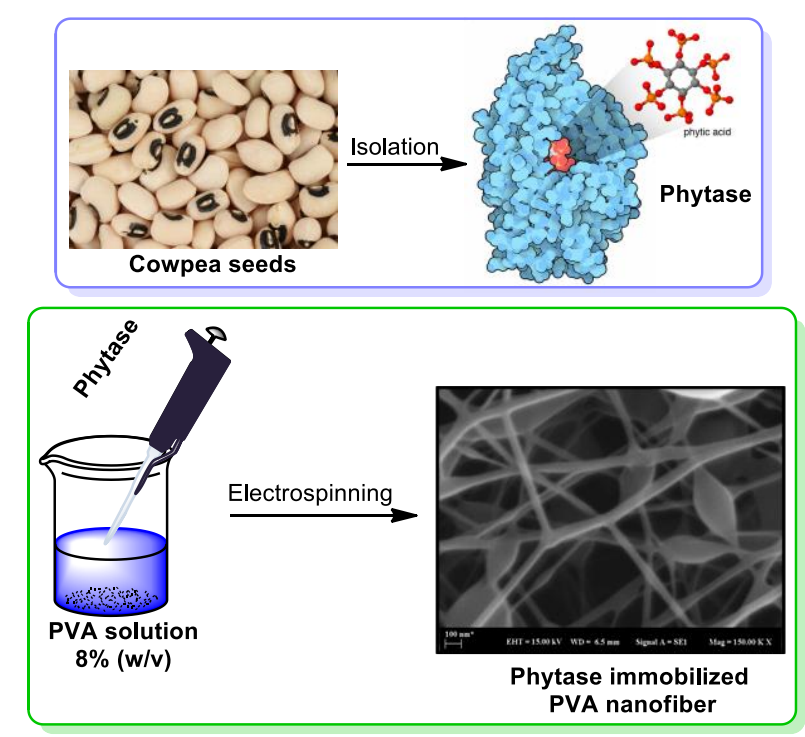

Figure 1. Fabrication of the enzyme-containing nanofibers.

\subsection{Measurements.}

The X-ray diffraction (XRD) measurement of PVA and phytase-PVA nanofibers was carried out using an X-ray diffractometer (Panalytical X'Pert PRO XRD, Cambridge, UK). The size distribution of the fibers was determined via Image $\mathrm{J}$ using 100 different fiber diameters to determine the average diameter of the fibers. Morphological properties of immobilized phytase into PVA nanofiber were also recorded by an FE-SEM (Zeiss EVO LS 10, Oberkochen, Germany). FT-IR spectra of the nanofibers and sodium phytate were measured using an FT-IR spectrophotometer (Thermo Scientific (Nicolet iS10), Paisley, UK) with an ATR sample unit.

\subsection{Phytase standard assay.}

Free phytase activity was determined as described via the Harland method [23] with slight modification as follows: $2 \mathrm{mM}$ substrate (sodium phytate) solution (100 $\mu \mathrm{L}$ ) was prepared in $0.1 \mathrm{M} \mathrm{NaOAc}$ buffer ( $\mathrm{pH}$ 5.0), and $350 \mu \mathrm{L} \mathrm{NaOAc}$ buffer solution was placed into the substrate solution. This mixture was incubated in a water bath for $10 \mathrm{~min}$ at $50{ }^{\circ} \mathrm{C}$. Then, $150 \mu \mathrm{L}$ enzyme was added to the mixture containing the substrate. This mixture was incubated for $30 \mathrm{~min}$ at the mentioned temperature above. After incubation of phytase with the substrate, the reaction was stopped by denaturing the phytase with $400 \mu \mathrm{L}$ trichloroacetic acid $(15 \%$, $w / v)$. The mixture was centrifuged at $5000 \mathrm{rpm}$ for $10 \mathrm{~min}$. To determine phytase activity, 0.2 $\mathrm{mL}$ supernatant was stirred with $1.8 \mathrm{~mL}$ distilled water and $2 \mathrm{~mL}$ color reagent $\left(3: 1: 1 ; \mathrm{H}_{2} \mathrm{SO}_{4}\right.$ $(1 \mathrm{M})$, ascorbic acid $(10 \% ; w / v)$, and ammonium molybdate $(2.5 \% ; w / v)$ was added to the 
mixture. The mixture was incubated for $15 \mathrm{~min}$ at $50^{\circ} \mathrm{C}$, and then it was cooled to ambient temperature, and the absorbance value was measured at $820 \mathrm{~nm}$ via a UV-Vis spectrophotometer. The same procedure was applied to the immobilized enzyme $(0.3 \mathrm{mg})$ into PVA nanofiber containing phytase.

\section{7. $p H$ and temperature effect on phytase activity.}

The effect of $\mathrm{pH}$ was investigated by incubating the enzymes with the substrate (Naphytate) in 0.1 M different buffer solutions: glycine- $\mathrm{HCl}$ (pH 2.0-3.0), $\mathrm{NaOAc}(\mathrm{pH} 4.0-6.0$ ), and Tris- $\mathrm{HCl}(\mathrm{pH} 7.0-9.0)$. Besides, the temperature effect was determined in the range from 25 to $95^{\circ} \mathrm{C}$, and the incubation temperature was changed at the mentioned temperatures.

\subsection{Thermal stability and kinetic parameters of free and immobilized phytase.}

The thermal stability of the enzyme was also studied, and they were incubated for 10 , 20 , and $30 \mathrm{~min}$ in the range from 30 to $90{ }^{\circ} \mathrm{C}$. The enzymatic activity was determined under the phytase standard assay to determine the enzymatic activity of phytase. Phytase activity was studied at different sodium phytate concentrations $(50-120 \mathrm{mM})$ under the phytase activity assay. $K_{m}$ and $V_{\max }$ values were found from the Lineweaver-Burk plot [24,25].

\section{Results and Discussion}

\subsection{Morphological properties and characterization of electrospun fibers.}

SEM images of PVA and PVA nanofiber containing phytase were given in Figure 2. As can be seen in Figure 2, PVA and phytase-PVA electrospun nanofibers have a smooth surface with a nanofiber structure. The fiber homogeneity was increased with the addition of the enzyme into the PVA solution. Moreover, phytase-PVA nanofiber was contained beads with an average diameter in the range of 94 to $197 \mathrm{~nm}$. This nanofiber structure with beads can offer protection and stability to the enzyme. Rathnayake and et al. stated that nanofibers containing a large number of beads in the structure were provided to extra stability to the enzyme, and this structure has protected the enzyme from the external condition [12].
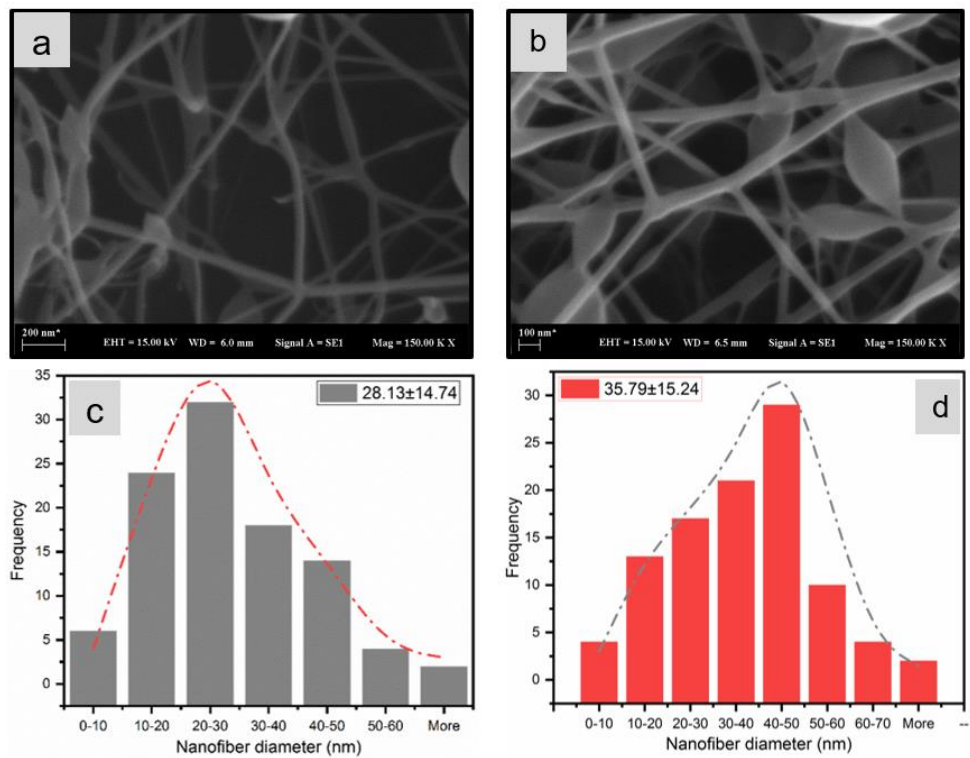

Figure 2. SEM image and size distribution of the fabricated PVA (a, c) and phytase-PVA (b, d) nanofibers at ambient conditions. 
The average diameter of the nanofibers is given in Figure 2. The fiber diameter of PVA and phytase-PVA nanofibers was determined in the range from 0 to 60 and 0 to $70 \mathrm{~nm}$, respectively, and the average diameter of the nanofibers was determined as $28.13 \pm 14.74$ and $35.79 \pm 15.24 \mathrm{~nm}$ for PVA and phytase-PVA, respectively.

X-ray diffraction (XRD) analysis of PVA and phytase-PVA nanofibers were carried out to evaluate the crystalline structure (Figure 3). The neat PVA nanofiber exhibited peaks at 9.08, 13.89, 17.16, 23.58, 25.86, and 27.22 ${ }^{\circ}$. The peak observed around $23.5^{\circ}$ could be considered a crystalline peak for PVA, and it was recorded due to hydrogen bonds in PVA [26]. The XRD peaks of phytase-PVA nanofiber were observed at 7.73, 13.02, 17.16, 19.59, 25.50 , and $27.22^{\circ}$. These peaks demonstrated that XRD peaks in the structure of phytase-PVA nanofiber were shifted to a lower $2 \theta$ angle. Moreover, some XRD peaks in the range from 35 to $60^{\circ}$ disappeared in the XRD pattern of phytase-PVA fiber due to the good dispersion of phytase into the polymer solution [16].

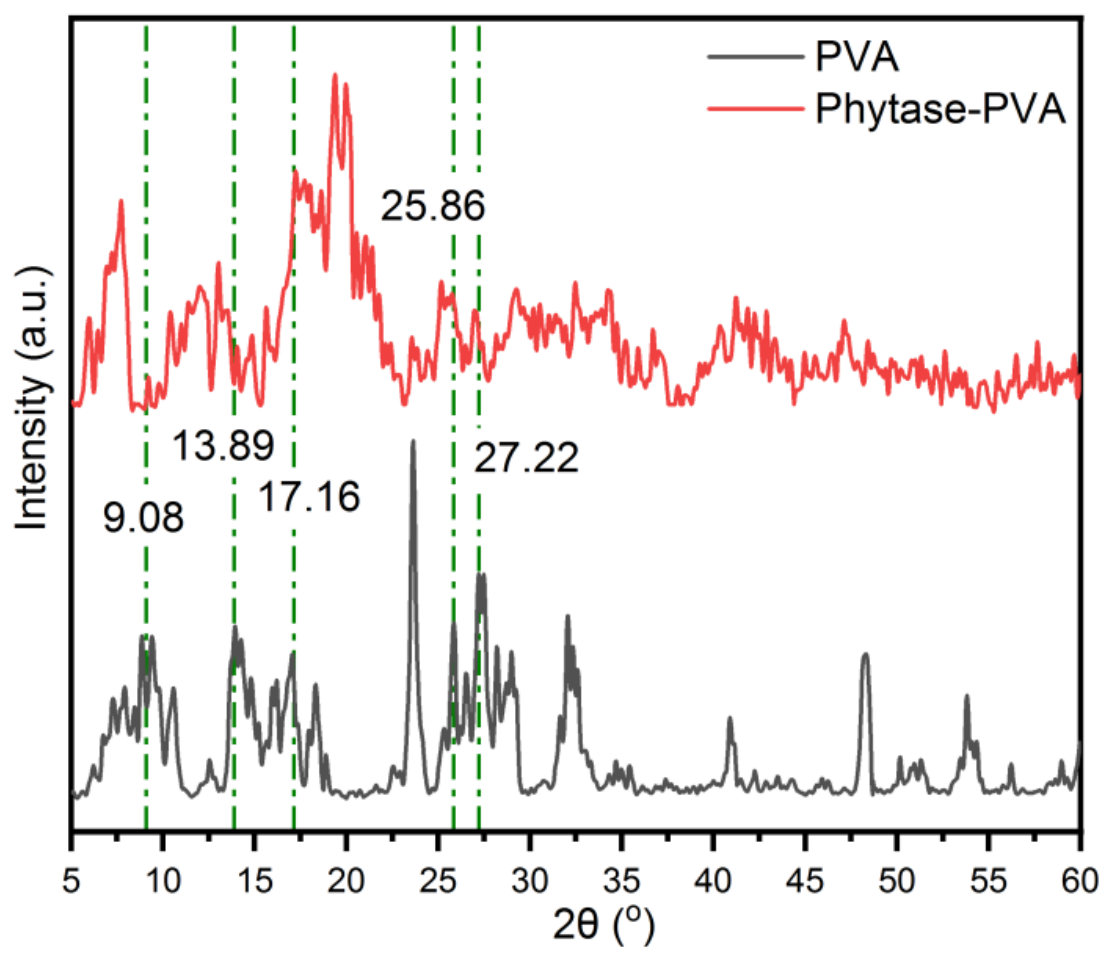

Figure 3. XRD pattern of the fabricated PVA and phytase-PVA nanofibers.

FT-IR spectra of the nanofibers and sodium phytate were given in Figure 4. The characteristic hydroxyl stretching (-OH) vibration of PVA was seen at $3289 \mathrm{~cm}^{-1}$. Aliphatic $\mathrm{CH}$ (Al-CH) stretching vibration and $-\mathrm{C}-\mathrm{O}$ stretching vibration of the acetyl group of PVA were observed at 2909 and $1076 \mathrm{~cm}^{-1}$, respectively [27]. A broad $-\mathrm{OH}$ stretching vibration of $1.5 \%$ phytase containing nanofibers was seen at $3264 \mathrm{~cm}^{-1}$. Al-CH and $-\mathrm{C}-\mathrm{O}$ stretching vibrations were also observed at 2919 and $1090 \mathrm{~cm}^{-1}$ for nanofibers containing $1.5 \%$ phytase, respectively. $\mathrm{PO}_{4}{ }^{3-}$ and $-\mathrm{C}-\mathrm{O}-\mathrm{P}$ stretching vibrations were seen at 1186 and $902 \mathrm{~cm}^{-1}$, respectively, in the substrate structure [28]. These stretching vibrations of PVA fibers containing $1.5 \%$ phytase were observed at 1320 and $916 \mathrm{~cm}^{-1}$, respectively. FT-IR results indicated that $-\mathrm{OH},-\mathrm{C}-\mathrm{O}, \mathrm{PO}_{4}{ }^{3-}$ and $-\mathrm{C}-\mathrm{O}-\mathrm{P}$ stretching vibrations in the structure of fibers containing $1.5 \%$ phytase showed a small displacement due to hydrogen bonding interaction between phytase and the hydroxyl group of PVA [29]. 


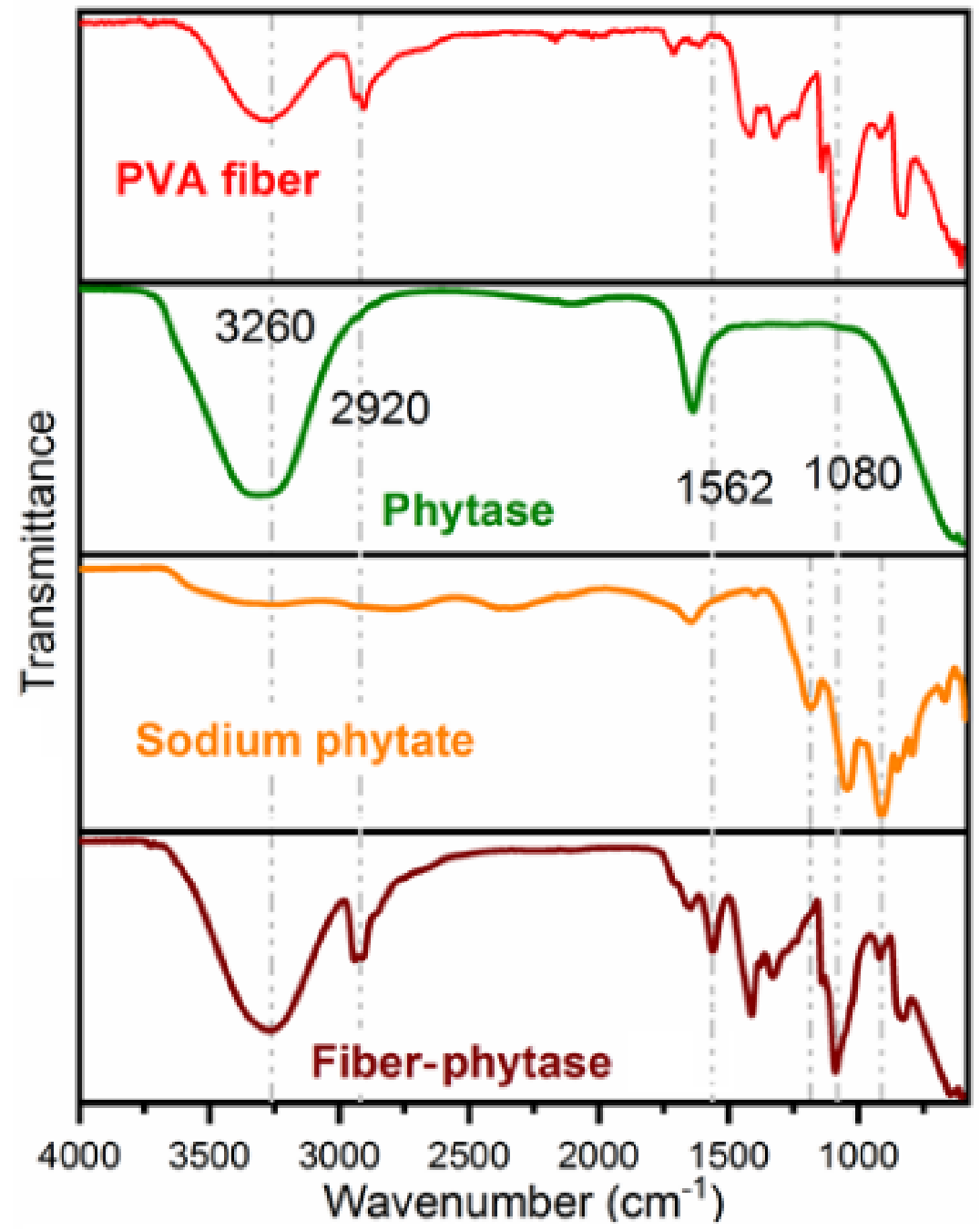

Figure 4. FT-IR spectra of PVA fiber, phytase, sodium phytate, and phytase containing nanofiber.

\section{2. $\mathrm{pH}$ and temperature effect on phytase activity.}

In the presence of amino acids, side chains of enzymes are affected by enzymatic activity at different $\mathrm{pH}$ values via protonation or deprotonation [30]. Figure 5a shows the $\mathrm{pH}$ effect on the free or immobilized phytase activity in the range of $\mathrm{pH}$ between 2 to 9 . Relative enzymatic activity of free phytase was found around 80,100 , and $70 \%$ for $\mathrm{pH} 4,5$, and 6 , respectively, and the enzyme was lost its activity around $\mathrm{pH}=8$ and 9. Relative activity of immobilized phytase was determined as $82,84,88,100,70$, and $65 \%$ for $\mathrm{pH} 2,3,4,5,6$, and 7 , respectively, and it was preserved its activity with 58 and $20 \%$ relative activity at $\mathrm{pH} 8$ and 9. According to these results, both free and immobilized enzymes have optimum enzymatic activity at $\mathrm{pH}$ 5. Moreover, $\mathrm{pH}$ effect results demonstrated that the $\mathrm{pH}$ stability of immobilized phytase showed higher relative enzymatic activity at a wide range of $\mathrm{pH}$ values. Phytase can be classified as acidic ( $\mathrm{pH}$ 5.0), neutral ( $\mathrm{pH}$ 7.0) and alkaline ( $\mathrm{pH} \mathrm{8.0)} \mathrm{related} \mathrm{to} \mathrm{the} \mathrm{enzymatic}$ activity values at optimum $\mathrm{pH}$. This value of the plant origin phytase was acidic $(\mathrm{pH}=5.0)$ $[31,32]$. Moreover, acidic phytase is more preferred for industrial applications due to substrate specificity, digestibility, and applicability of this phytase type [33].

The temperature effect of the free or immobilized enzyme was studied using $2.5 \mathrm{mg}$ PVA fiber containing $1.5 \%$ phytase (Figure $5 \mathrm{~b}$ ) under optimum conditions. Relative phytase activity of the free enzyme was increased between 25 and $45^{\circ} \mathrm{C}$, and the maximum enzymatic activity was obtained at $45{ }^{\circ} \mathrm{C}$. After $45{ }^{\circ} \mathrm{C}$, its enzymatic activity was decreased. Relative 
enzymatic activity of immobilized phytase was increased between $25^{\circ} \mathrm{C}$ and $65^{\circ} \mathrm{C}$, and its maximum enzymatic activity was determined as $65^{\circ} \mathrm{C}$, and then it was decreased very slowly. These results showed that the relative enzymatic activity of immobilized phytase was shifted to $65^{\circ} \mathrm{C}$, and the optimum temperature of the immobilized phytase was increased compared to the free phytase. This increase could probably be the secondary interaction such as ionic or hydrophobic interactions and hydrogen bonds between phytase and support materials. Poly(vinyl alcohol) (PVA), which is a hydroxyl group (-OH) rich polymer, has been used to support material in this study. This polymer has been changed the optimum temperature of the immobilized enzyme because of its ability to withstand high temperatures [34]. Moreover, the results obtained from enzymatic activity studies for $\mathrm{pH}$ and temperature indicated that immobilized phytase has catalytic activity in a wider $\mathrm{pH}$ range and a higher optimum temperature. These properties are quite important for industrial applications of phytase.
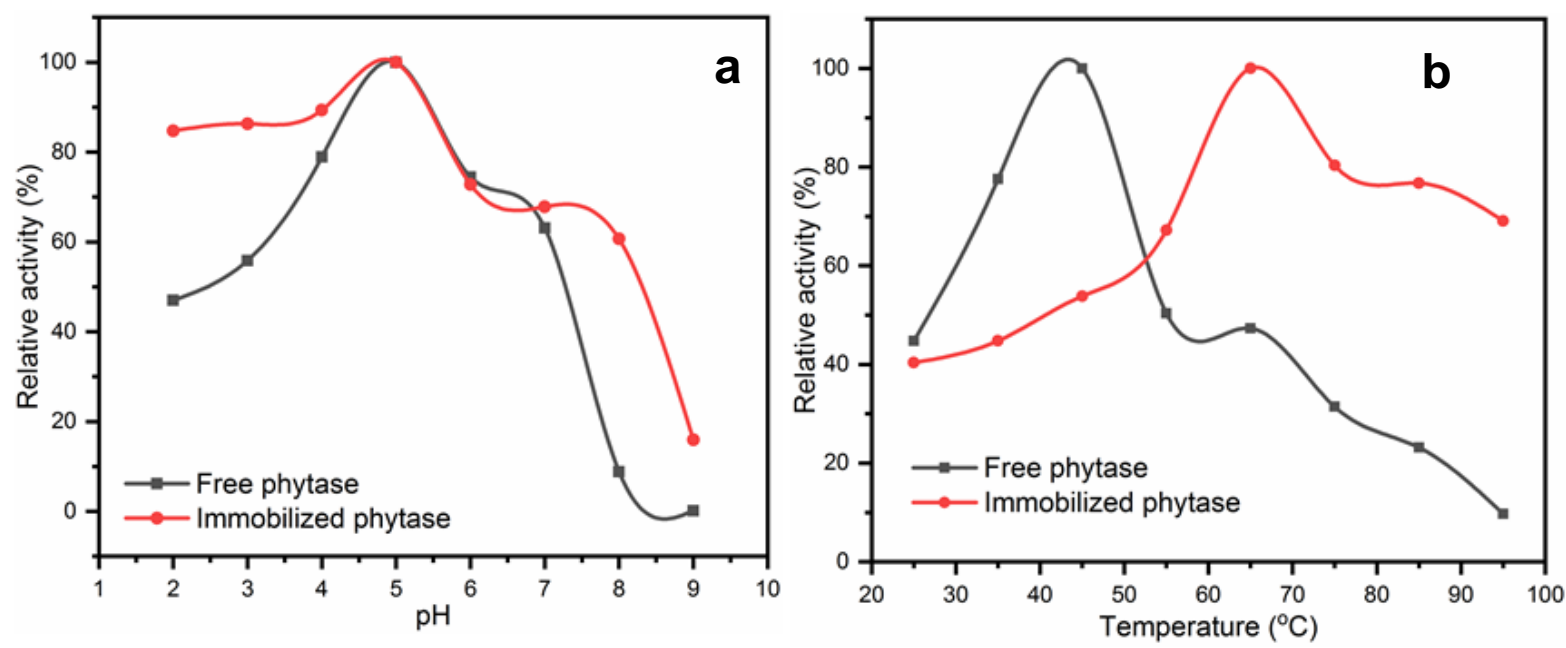

Figure 5. pH (a) and temperature (b) effect on free and immobilized phytase activity in the presence of $2.5 \mathrm{mg}$ nanofiber containing $1.5 \%$ phytase.

\subsection{Thermal stability and kinetic parameters.}

Figure 6a shows the thermal stability of free and immobilized phytase at different temperatures $\left(30-90^{\circ} \mathrm{C}\right)$. As seen in the thermal stability curve, the free phytase preserved $84.3 \%$ initial enzymatic activity during $50^{\circ} \mathrm{C}$, and the relative activity of phytase dramatically decreased after this temperature. The relative activity of immobilized phytase was increased in the range from $30(69.4 \%)$ to $50^{\circ} \mathrm{C}(80.3 \%)$, and it was slightly decreased at 60 and $70^{\circ} \mathrm{C}$. Also, immobilized phytase showed higher thermal stability at 80 and $90^{\circ} \mathrm{C}$, and it exhibited significant thermal stability against temperature change. Naghshbandi et al. stated that the enhanced thermal stability of the immobilized phytase was attributed to the structure of support materials, reduction in the molecular interaction between phytase and the supporting materials, and decrease in the mobility of protein [35].

The incubation time effect on relative enzymatic activity was given in Figure $6 \mathrm{~b}$ at 50 and $80{ }^{\circ} \mathrm{C}$. As shown in Figure $6 \mathrm{~b}$, the free enzyme has higher enzymatic activity at $50{ }^{\circ} \mathrm{C}$ than the immobilized phytase. Also, increasing the temperature, the enzymatic activity of immobilized phytase was increased, whereas the enzymatic activity of the free phytase was decreased, and it became more stable to the temperature after immobilization. 

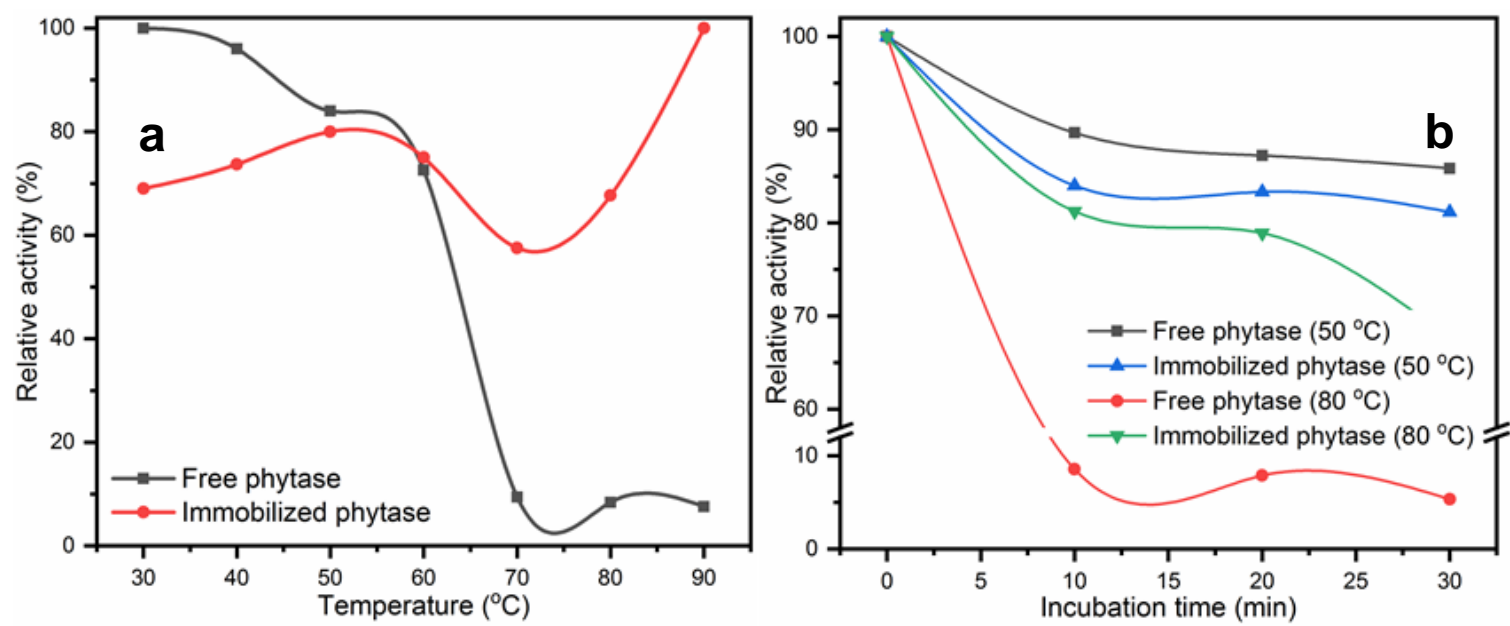

Figure 6. Thermal stability of free and immobilized phytase at $30 \mathrm{~min}$ incubation time (a), and incubation time effect on enzyme activity at $60{ }^{\circ} \mathrm{C}$ in the presence of $2.5 \mathrm{mg}$ nanofiber at $\mathrm{pH} 5.0$ (b).

Enzymatic activity was also investigated in the presence of different concentrations of sodium phytate to determine the $K_{m}$ and $V_{\max }$ values. $K_{m}$ and $V_{\max }$ values were calculated from the Lineweaver-Burk equation as $0.46 \mathrm{mM}$ and $53.76 \mathrm{U} / \mathrm{mg}$ protein for the free phytase and $1.17 \mathrm{mM}$ and $5.67 \mathrm{U} / \mathrm{mg}$ protein for immobilized phytase, respectively. These results showed that the Michaelis-Menten constant $\left(K_{m}\right)$ value of immobilized phytase was increased after enzyme immobilization into PVA fiber. As known, enzyme-substrate affinity was decreased with an increased $K_{m}$ value. This could have probably pored the structure of the fibers. Isik et $a l$. stated that the $K_{m}$ value of immobilized phytase was increased because of sodium phytate diffusion problems and steric hindrance [16]. In the presence of these factors, the enzyme active centers or porous structure of fiber may be blocked in the fiber fabrication process [36].

Fabrication of the polymer-based nanofibers for phytase immobilization as support material has not been studied except only in a few papers. Among these papers, Rathnayake $e t$ $a l$. were fabricated rice bran-based electrospun nanofibers with a diameter of $20-50 \mathrm{~nm}$, and the thermal stability of the immobilized enzyme was enhanced after immobilization [12]. In another paper, Harati et al. were obtained polyacrylamide and starch-based nanofibers for phytase immobilization. $K_{m}$ and $V_{\max }$ values of the immobilized phytase were found as $56 \mu \mathrm{M}$, and $401 \mu \mathrm{mol} / \mathrm{min} \mathrm{mg}$, respectively, and the optimum $\mathrm{pH}$ and temperature were not changed after immobilization [37]. In the present manuscript, the kinetic parameters of the free and immobilized enzymes were calculated very closely. Also, the optimum temperature of the immobilized phytase was shifted to high temperature, and the immobilized phytase exhibited catalytic activity in a wider $\mathrm{pH}$ range.

The fabricated PVA nanofibers were also compared with the reported nano-based supporting materials in literature (Table 1) [11,22,37,38].

Table 1. Performance comparison of PVA nanofiber as supporting materials with the other materials.

\begin{tabular}{|c|c|c|c|c|}
\hline \multirow{2}{*}{$\begin{array}{l}\text { Supporting } \\
\text { materials }\end{array}$} & \multirow{2}{*}{$\begin{array}{l}\text { Phytase } \\
\text { source }\end{array}$} & \multicolumn{2}{|c|}{$\mathbf{K m}$} & \multirow[b]{2}{*}{ References } \\
\hline & & Free enzyme & $\begin{array}{c}\text { Immobilized } \\
\text { enzyme }\end{array}$ & \\
\hline $\begin{array}{l}\text { Amino-multiwalled } \\
\text { carbon nanotubes }\end{array}$ & Bacterial & $0.13 \mathrm{mM}$ & $0.33 \mathrm{mM}$ & 11 \\
\hline PVA-CS nanofiber & Plant & $0.46 \mathrm{mM}$ & $13.43 \mathrm{mM}$ & 22 \\
\hline $\begin{array}{l}\text { Nanofibers-based on } \\
\text { polyacrylamide }\end{array}$ & Microbial & $86 \mu \mathrm{M}$ & $56 \mu \mathrm{M}$ & 37 \\
\hline Graphene oxide & Bacterial & $1.45 \mathrm{mM}$ & $0.44 \mathrm{mM}$ & 38 \\
\hline PVA nanofiber & Plant & $0.46 \mathrm{mM}$ & $1.17 \mathrm{mM}$ & This study \\
\hline
\end{tabular}


As can be seen from Table 1, the obtained results in this study are quite consistent with the results reported in the literature.

\section{Conclusions}

In this paper, phytase was partially purified from cowpea seeds, and it was immobilized into PVA nanofibers. Physicochemical characterizations of free and immobilized phytase such as kinetic $\left(K_{m}\right.$ and $V_{\max }$ ), optimum $\mathrm{pH}$, and temperature were also done. Enzymatic activity results to determine optimum $\mathrm{pH}$ and temperature indicated that immobilized phytase has enzymatic activity in a wider $\mathrm{pH}$ range and the optimum temperature at a higher temperature. These properties are quite important for industrial application phytase. Thermal stability experiments were carried out by incubating the enzyme at different temperatures, and the enzymatic activity of immobilized phytase has higher thermal stability at high temperatures. The results showed that immobilized phytase on PVA nanofiber is highly suitable for agriculture, animal feed, food, and medical applications.

\section{Funding}

This research received no external funding.

\section{Acknowledgments}

This study was supported by the YTU-BAP Coordinator (Project no: No: 2015-01-02-DOP06; project ID: 839).

\section{Conflicts of Interest}

The authors declare no conflict of interest.

\section{References}

1. Morshed, M.N.; Behary, N.; Bouazizi, N.; Guan, J.; Nierstrasz, V.A. An overview on biocatalysts immobilization on textiles: Preparation, progress and application in wastewater treatment. Chemosphere 2021, 279, https://doi.org/10.1016/j.chemosphere.2021.130481.

2. Ellis, L.D., Rorrer, N.A., Sullivan, K.P., Otto, M., McGeehan, J.E., Roman-Leshkov, Y., Wierckx, N., Beckham, G.T. Chemical and biological catalysis for plastics recycling and upcycling. Nat. Catal. 2021, 4, 539-556, https://doi.org/10.1038/s41929-021-00648-4.

3. Messing, R. Immobilized enzymes for industrial reactors. Elsevier 2012, https://doi.org/10.1016/B978-0-12492350-8.X5001-4.

4. Kumari, A., Rajeev, R., Benny, L., Sudhakar, Y.N., Varghese, A., Hegde, G. Recent advances in carbon nanotubes-based biocatalysts and their applications. Adv. Colloid Interface Sci. 2021, 297, https://doi.org/10.1016/j.cis.2021.102542.

5. Naramittanakul, A.; Buttranon, S.; Petchsuk, A.; Chaiyen, P.; Weeranoppananti, N. Development of a continuous-flow system with immobilized biocatalysts towards sustainable bioprocessing. React. Chem. Eng. 2021, 6, 1771-1790, https://doi.org/10.1039/D1RE00189B.

6. Lei, X.G.; Weaver J.D.; Mullaney E.; Ullah A.H.; Azain, M.J. Phytase, a new life for an "old” enzyme. Annu. Rev. Anim. Biosci. 2013, 1, 283-309, https://doi.org/10.1146/annurev-animal-031412-103717.

7. Gharibzahedi, S.M.T., Smith, B. Legume proteins are smart carriers to encapsulate hydrophilic and hydrophobic bioactive compounds and probiotic bacteria: A review. Compr. Rev. Food Sci. Food Saf. 2021, 20, 1250-1279, https://doi.org/10.1111/1541-4337.12699.

8. Mullaney E.J.; Ullah, A.H. The term phytase comprises several different classes of enzymes. Biophys. Res. Commun. 2003, 312, 179-184, https://doi.org/10.1016/j.bbrc.2003.09.176.

9. Bhavsar, K.; Khire, J. Current research and future perspectives of phytase bioprocessing. RSC Adv. 2014, 4, 26677-26691, https://doi.org/10.1039/C4RA03445G. 
10. Hussain, S.M., Hanif, S., Sharif, A., Bashir, F., Iqbal, H.M.N. Unrevealing the Sources and Catalytic Functions of Phytase with Multipurpose Characteristics. Catal. Lett. 2021, https://doi.org/10.1007/s10562021-03752-z.

11. Coutinho, T.C.; Tardioli, P.W.; Farinas C.S. Phytase immobilization on hydroxyapatite nanoparticles improves its properties for use in animal feed/ Appl. Biochem. Biotech. 2020, 190, 270-292, https://doi.org/10.1007/s12010-019-03116-9.

12. Rathnayake, U.A.; Senapathi, T.; Sandaruwan, C.; Gunawardene, S.; Karunaratne, V.; Kottegoda, N. Rice bran nanofiber composites for stabilization of phytase. Chem. Cent. J. 2018, 12, 1-7, https://doi.org/10.1186/s13065-018-0400-y.

13. Aytac, Z.; Dogan, S.Y.; Tekinay, T.; Uyar, T. Release and antibacterial activity of allyl isothiocyanate/ $\beta$ cyclodextrin complex encapsulated in electrospun nanofibers. Colloids Surf. B 2014, 120, 125-131, https://doi.org/10.1016/j.colsurfb.2014.04.006.

14. Santos, J.P.; Zavareze, E.R.; Dias, A.R.G.; Vanier. N.L. Immobilization of xylanase and xylanase- $\beta$ cyclodextrin complex in polyvinyl alcohol via electrospinning improves enzyme activity at a wide $\mathrm{pH}$ and temperature range. Int. J. Biol. Macromol. 2018, 118, 1676-1684, https://doi.org/10.1016/j.ijbiomac.2018.07.014.

15. Joshi, B., Samuel, E., Kim, Y., Yarin, A.L., Swihart, M.T., Yoon, S.S. Progress and potential of electrospinning-derived substrate-free and binder-free lithium-ion battery electrodes. Chem. Eng. J. 2022, 430, https://doi.org/10.1016/j.cej.2021.132876.

16. Isik, C.; Arabaci, G.; Dogac, Y.I.; Deveci, I.; Teke, M. Synthesis and characterization of electrospun $\mathrm{PVA} / \mathrm{Zn}^{2+}$ metal composite nanofibers for lipase immobilization with effective thermal, $\mathrm{pH}$ stabilities and reusability. Mater. Sci. Eng. C 2019, 99, 1226-1235, https://doi.org/10.1016/j.msec.2019.02.031.

17. Godakanda, V.U.; Li, H.; Alquezar, L.; Zhao, L.; Zhu, L.M.; Silva, R.; Williams, G.R. Tunable drug release from blend poly(vinyl pyrrolidone)-ethyl cellulose nanofibers. Int. J. Pharm. 2019, 562, 172-179, https://doi.org/10.1016/j.ijpharm.2019.03.035.

18. Zhang, Y., Zhang, C., Wang, Y. Recent progress in cellulose-based electrospun nanofibers as multifunctional materials. Nanoscale Adv. 2021, https://doi.org/10.1039/d1na00508a.

19. Sun, Y.; Cheng, S.; Lu, W.; Wang, Y.; Zhang, P.; Yao, Q. Electrospun fibers and their application in drug controlled release, biological dressings, tissue repair, and enzyme immobilization. RSC Adv. 2019, 9, 2571225729, https://doi.org/10.1039/C9RA05012D.

20. Sharma, D., Saha, S., and Satapathy, B.K. Recent advances in polymer scaffolds for biomedical applications. J. Biomater. Sci. Polym. Ed. 2021, https://doi.org/10.1080/09205063.2021.1989569.

21. Guzik, U.; Hupert-Kocurek, K.; Wojcieszyńska, D. Immobilization as a strategy for improving enzyme properties-application to oxidoreductases. Molecules 2014, 19, 8995-9018, https://doi.org/10.3390/molecules19078995.

22. Duru Kamaci, U.; Peksel, A. Fabrication of PVA-chitosan-based nanofibers for phytase immobilization to enhance enzymatic activity. Int. J. Biol. Macromol. 2020, 164, 3315-3322, https://doi.org/10.1016/j.ijbiomac.2020.08.226.

23. Duru Kamaci, U.; Peksel, A. Enhanced catalytic activity of immobilized phytase into polyvinyl alcoholsodium alginate based electrospun nanofibers. Catal. Lett. 2021, 151, 821-831, https://doi.org/10.1007/s10562-020-03339-0.

24. Yildiz, H.B.; Kamaci, M.; Azak, H.; Secgin, O.; Suer, O. A comparative study: Immobilization of yeast cells and invertase in poly(ethyleneoxide) electrodes. J. Mol. Catal. B Enzym. 2013, 91, 52-58, https://doi.org/10.1016/j.molcatb.2013.02.009.

25. Aydin, F.; Turkoglu, V.; Bas, Z. Purification and characterization of angiotensin-converting enzyme (ACE) from sheep lung. Mol. Biol. Rep. 2021, 48, 4191-4199, https://doi.org/10.1007/s11033-021-06432-8.

26. Allafchian, A.R.; Kalani, S.; Golkar, P.; Mohammadi, H.; Jalali, S.A.H. A comprehensive study on Plantago ovata/PVA biocompatible nanofibers: Fabrication, characterization, and biological assessment. J. Appl. Polym. Sci. 2020, 137, https://doi.org/10.1002/app.49560.

27. Soni, S.K.; Sarkar, S.; Selvakannan, P.R.; Sarkar, D.; Bhargava, S.K. Intrinsic therapeutic and biocatalytic roles of ionic liquid mediated self-assembled platinum-phytase nanospheres. RSC Adv. 2015, 5, 6287162881, https://doi.org/10.1039/C5RA11273G.

28. Manjunath, A.; Irfan, M.; Anushree, K.P.; Vinutha, K.M.; Yamunarani, N. Synthesis and characterization of $\mathrm{CuO}$ nanoparticles and $\mathrm{CuO}$ doped PVA nanocomposites. Adv. Mater. Phys. Chem. 2016, 6, 263-273, https://doi.org/10.4236/ampc.2016.610026.

29. Duru Kamaci, U.; Kamaci, M. Preparation of polyvinyl alcohol, chitosan and polyurethane-based pHsensitive and biodegradable hydrogels for controlled drug release applications. Int. J. Polym. Mater. Po. 2020, 69, 1167-1177, https://doi.org/10.1080/00914037.2019.1670180.

30. Nelson, D.; Cox, M. Lehninger principles of biochemistry. WH Freeman and Company, New York, 2008.

31. Nunes, C.S.; Kumar, V. Enzymes in human and animal nutrition principles and perspectives. Academic Press, 2018.

32. Zhao, T.; Yong, X.; Zhao, Z.; Dolce, V.; Li, Y.; Curcio, R. Research status of Bacillus phytase. 3 Biotech. 2021, 11, https://doi.org/10.1007/s13205-021-02964-9. 
33. Dersjant-Li, Y.; Awati, A.; Schulze, H.; Partridge, G. Phytase in non-ruminant animal nutrition: A critical review on phytase activities in the gastrointestinal tract and influencing factors. J. Sci. Food Agric. 2015, 95, 878-896, https://doi.org/10.1002/jsfa.6998.

34. Bonine, B.M.; Polizelli, P.P.; Rodriguez, G.O.B. Immobilization of a plant lipase from pachira aquatica in alginate and alginate/PVA beads. Enzyme Res. 2014, 738739, 1-7, https://doi.org/10.1155/2014/738739.

35. Naghshbandia, M.P.; Moghimia, H.; Latif, B. Covalent immobilization of phytase on the multi-walled carbon nanotubes via diimide-activated amidation. Artif. Cell Nanomed. B 2018, 46, 763-772, https://doi.org/10.1080/21691401.2018.1435550.

36. Yildiz, H.B.; Caliskan. S.; Kamaci, M.; Caliska, A.; Yilmaz, H. L-Dopa synthesis catalyzed by tyrosinase immobilized in poly(ethyleneoxide) conducting polymers. Int. J. Biol. Macromol. 2013, 6, 34-40, https://doi.org/10.1016/j.ijbiomac.2013.01.031.

37. Harati, J.; Siadat, S.O.R.; Taghavian, H.; Kaboli, S.; Khorshidi, S. Improvement in biochemical characteristics of glycosylated phytase through immobilization on nanofibers. Biocatal. Agric. Biotechnol. 2017, 12, 96-103, https://doi.org/10.1016/j.bcab.2017.08.009.

38. Dutta, N.; Raj, D.; Biswas, N.; Mallick, M.; Omesh, S. Nanoparticle assisted activity optimization and characterization of a bacterial phytase immobilized on single layer graphene oxide, Biocatal. Agric. Biotechnol. 2017, 9, 240-247, https://doi.org/10.1016/j.bcab.2017.01.008. 